\title{
Effects of sucrose and glycerol on vitrification of buffalo oocytes
}

\author{
M. A. Hossain ${ }^{1}$, Shahrina Akter¹, M. F. H. Miraz², M. Nuronnabi Islam¹, \\ Jannatul Bari ${ }^{1}$, M. Hasanur Alam ${ }^{1}$, M. Bodruzzaman Sarker ${ }^{1}$, M. E. Kabir ${ }^{3}$, \\ A. Khatun', M. A. Hashem ${ }^{1}$, M. Moniruzzaman ${ }^{1 *}$
}

\begin{abstract}
${ }^{1}$ Department of Animal Science, Bangladesh Agricultural University, Mymensingh, Bangladesh ${ }^{2}$ Biotechnology Division, Bangladesh Livestock Research Institute, Savar, Dhaka, Bangladesh

${ }^{3}$ Department of Animal Production and Management, Sher-e-Bangla Agricultural University, Dhaka, Bangladesh
\end{abstract}

Received: 15 May 2021

Revised: 06 June 2021

Accepted: 08 June 2021

\section{*Correspondence:}

M. Moniruzzaman,

E-mail: monir.as@bau.edu.bd

Copyright: (c) the author(s), publisher and licensee Medip Academy. This is an open-access article distributed under the terms of the Creative Commons Attribution Non-Commercial License, which permits unrestricted non-commercial use, distribution, and reproduction in any medium, provided the original work is properly cited.

\begin{abstract}
Background: Vitrification, ultra-rapid cooling can be used to cryopreserve oocytes for embryo technology. The objective of this study was to evaluate the effects of sucrose and glycerol on vitrification of buffalo oocytes.

Methods: Cumulus-oocyte complexes (COCs) were aspirated from slaughtered buffalo ovaries. In experiment 1 , the vitrification solution was supplemented with either $0,0.25$ or $0.5 \mathrm{M}$ sucrose. In experiment 2 , the vitrification solution was supplemented with either 0,5 or $10 \mathrm{M}$ glycerol together with $0.5 \mathrm{M}$ sucrose. COCs were exposed into equilibration solution and vitrification solution for $5 \mathrm{~min}$ and $1 \mathrm{~min}$, respectively. Then the oocytes were submerged into liquid nitrogen for $10 \mathrm{~min}$ using cryotops. The oocytes were thawed, diluted and washed in washing solution. Vitrified oocytes were cultured for maturation at $38.5^{\circ} \mathrm{C}$ for $24 \mathrm{hrs}$ at $5 \% \mathrm{CO}_{2}$. Then oocytes were fixed in acetic acid and ethanol and stained with aceto-orcein to examine the meiotic stages.

Results: In experiment 1, a significantly higher number of morphologically normal oocytes and cumulus cell expansion were found in $0.5 \mathrm{M}$ sucrose group than others. In addition, a proportion of oocytes resumed meiosis but none of those developed to the metaphase II (MII) stage. In experiment 2, a significantly higher number of oocytes showed cumulus cell expansion as well as higher morphologically normal oocytes in $5 \mathrm{M}$ and $10 \mathrm{M}$ glycerol than in $0 \mathrm{M}$ (control) group. In addition, $18 \%$ oocytes matured to the MII stage in $5 \mathrm{M}$ glycerol group.

Conclusions: Buffalo oocytes can be vitrified with a combination of sucrose and glycerol to maintain its developmental potential.
\end{abstract}

Keywords: Buffalo, Glycerol, In vitro maturation, Oocytes, Sucrose, Vitrification

\section{INTRODUCTION}

The buffalo (Bubalus bubalis, L.) is an important component of livestock in several countries in the world. One of the banes of buffalo production is low reproductive performance. ${ }^{1}$ The response to multiple ovulation and embryo transfer (MOET) techniques is poor in buffaloes. ${ }^{2}$ The problem of in vitro embryo production (IVEP) technology in buffalo is the low number of oocytes that can be recovered from donors. This phenomena arises from physiological peculiarities of the species such as the low number of primordial and antral follicles present in the buffalo ovary as well as the high incidence of follicular atresia and as such, it is not easily improvable. ${ }^{3}$ The scarcity of buffalo oocytes is a drawback for exploiting embryo technologies. Cryopreservation of oocytes collected from slaughtered buffaloes might increase the availability of buffalo oocytes for reproductive technologies. 
Cryopreservation could be conducted through vitrification which is an ultra-rapid cooling technique. ${ }^{4}$ The advances of vitrification methods have simplified the cryopreservation procedures. Different cryoprotectants like ethylene glycol (EG), glycerol (GLY), dimethylsulfoxide (DMSO), propylene glycol and 1, 2propanediol $(\mathrm{PROH})$ and sucrose have been used in different combinations for vitrification of buffalo oocytes and embryos. ${ }^{5}$ EG is considered an important cryoprotectant due to its higher penetrating ability with low toxicity. ${ }^{6}$ DMSO has been used for vitrification of oocytes in many species including buffalo and cattle. ${ }^{7,8}$

Sugar molecules including sucrose, trehalose, glucose, fructose, ficoll and raffinose are used in cryopreservation of oocytes and embryos to prevent osmotic shock and reduce cytotoxicity. ${ }^{9}$ The addition of sugar equalizes osmolality between the extracellular diluting solution and the intracellular solution. ${ }^{10}$ The damage caused by intracellular ice formation cannot be prevented, but it can be significantly minimized by cellular dehydration. ${ }^{11}$ Disaccharides have been used for vitrification of oocytes and embryos in species such as mouse, rabbit, sheep, horse, cattle, buffalo and human embryos. ${ }^{12-18}$ They have also used for oocytes studies in mouse, cattle, buffalo and human. ${ }^{19-23}$ The effects of different sugars (glucose, sucrose or a polysaccharide) as non-permeant cryoprotectants in vitrification media on in vitro maturation of vitrified-warmed immature $(\mathrm{GV})$ porcine oocytes have been studied and indicate that sucrose-treated oocytes have higher maturation rates compared to oocytes vitrified in glucose supplemented cryoprotectant. ${ }^{24}$

Glycerol has been used as a cryoprotectant in combination with EG and/or DMSO during oocyte vitrification in buffaloes. $^{7,25}$ Glycerol-treated oocytes show higher DNA methylation compared with DMSO and fresh oocytes. The present study was aimed to examine the effect of supplementing sucrose and glycerol in EG and DMSO based cryoprotectant in in vitro maturation of buffalo oocytes.

\section{METHODS}

This study was conducted in the department of animal science, Bangladesh agricultural university, Mymesningh, Bangladesh during the period from July 2015 to June 2017.

\section{Chemicals}

All culture-grade chemicals were purchased from SigmaAldrich (St. Louis, MO) unless otherwise mentioned.

\section{Collection of COCs}

Buffalo ovaries were collected from a local slaughterhouse (Kaptan Bazar, Dhaka) without considering the season of animal slaughter and transported to the laboratory in $0.9 \%$ normal saline at $37^{\circ} \mathrm{C}$. The ovaries were washed in Dulbecco's phosphate buffer saline (DPBS) solution supplemented with gentamycin sulfate $(50 \mathrm{mg} / \mathrm{ml})$ once and rinsed three times in DPBS. Visible antral follicles (4$8 \mathrm{~mm}$ in diameter) were aspirated using a 20 gauge needle attached to a $10 \mathrm{ml}$ syringe to collect COCs. The COCs were screened under a stereomicroscope and washed three times in TCM-199 (pH 7.4, Nissui Pharmaceutical, Tokyo, Japan) containing $0.85 \mathrm{mg} / \mathrm{ml} \mathrm{NaHCO}_{3}, 0.08 \mathrm{mg} / \mathrm{ml}$ gentamycin sulfate and $25 \mathrm{mM}$ HEPES in a plastic dish (No. 1008, Falcon, Becton Dickinson and Company, Franklin lakes, NJ, USA) for vitrification. COCs containing healthy oocytes (120-130 $\mu \mathrm{m}$ in diameters) were selected based on their morphological appearance (uniformly granulated cytoplasm surrounded by multilayered COCs) for vitrification. ${ }^{26}$

\section{Vitrification and warming of COCs}

COCs were vitrified following the procedure of our previous reports. ${ }^{27,28}$ The basic solution (M-199) was TCM-199 containing $2.5 \mathrm{mg} / \mathrm{ml}$ HEPES, $2.47 \mathrm{mg} / \mathrm{ml} \mathrm{Na}-$ HEPES, $0.35 \mathrm{mg} / \mathrm{ml} \mathrm{NaHCO} 3$ and $0.05 \mathrm{mg} / \mathrm{ml}$ gentamycin sulfate. The equilibration solution was M-199 containing $7.5 \%(\mathrm{v} / \mathrm{v})$ EG, $7.5 \%(\mathrm{v} / \mathrm{v})$ DMSO and $20 \%$ FBS. The basic vitrification solution consisted of $15 \%(\mathrm{v} / \mathrm{v}) \mathrm{EG}$, $15 \%(\mathrm{v} / \mathrm{v})$ DMSO and 20\% FBS in M-199.

In the first experiment, vitrification solution was supplemented with either $0,0.25$, or $0.5 \mathrm{M}$ sucrose. The warming solution was $20 \%$ fetal calf serum (FCS) in M199 that contained either $0,0.25$ or $0.5 \mathrm{M}$ sucrose, depending on the sucrose concentrations of the vitrification solution. The dilution solution was $20 \%$ FCS in M-199 containing either $0,0.25$ or $0.5 \mathrm{M}$ sucrose. The washing solution contained $20 \%$ FCS in M-199. In the second experiment, vitrification solution was supplemented with either 0,5 or $10 \mathrm{M}$ glycerol together with $0.5 \mathrm{M}$ sucrose. The warming solution contained 0,5 or $10 \mathrm{M}$ glycerol together with $0.5 \mathrm{M}$ sucrose. The dilution solution further contained either 0,5 or $10 \mathrm{M}$ of glycerol together with $0.5 \mathrm{M}$ of sucrose. The washing solution contained $20 \%$ FCS in M-199.

At first, COCs were treated with equilibration solution at room temperature for $5 \mathrm{~min}$. COCs were transferred to vitrification solution for $1 \mathrm{~min}$. Then, 3-5 COCs were loaded on the filmstrip of a cryotop (Kitazato Inc., Japan) and immediately submerged into liquid nitrogen $\left(\mathrm{LN}_{2}\right)$ for $10 \mathrm{~min}$. Before vitrification, the surrounding vitrification solution was removed by gentle aspiration, leaving a thin layer around the oocytes. After vitrification, the oocytes were warmed in thawing solution for $5 \mathrm{~min}$. Then, the COCs were treated with dilution solution for $5 \mathrm{~min}$. Before allowing the oocytes for in vitro maturation, they were passed through washing solution for $5 \mathrm{~min}$ to remove the cryoprotectants. The COCs were evaluated for morphological quality as described previously. ${ }^{26}$ Briefly, COCs with multilayered compact cumulus cells and a good integrity between oolemma and zona pellucida were classified as morphologically normal COCs. The COCs with normal morphology were subsequently used for in vitro maturation and the rest were discarded. 
with normal morphology were subsequently used for in vitro maturation and the rest were discarded.

\section{In vitro maturation (IVM)}

The basic medium for oocytes maturation was tissue culture medium-199 (TCM-199, Earle's salt with Lglutamine) and sodium bicarbonate. On the day of maturation, TCM-199 was supplemented with $0.1 \mathrm{mg} / \mathrm{ml}$ sodium pyruvate, $0.08 \mathrm{mg} / \mathrm{ml}$ gentamycin sulfate, $5 \%(\mathrm{v} / \mathrm{v})$ FBS and $100 \mathrm{ng} / \mathrm{ml}$ follicle stimulating hormone (FSH; NIDDK, Washington, DC, USA). The vitrified-thawed COCs were washed three times in maturation media. COCs were placed in $100 \mu \mathrm{l}$ IVM-media droplets in 35 $\mathrm{mm}$ petri dish under mineral oil and incubated at $38.5^{\circ} \mathrm{C}$, $5 \% \mathrm{CO}_{2}$ in humidified air. After $24 \mathrm{hrs}$ of incubation, oocytes were observed under the microscope for cumulus expansion. The assessment of cumulus cell expansion was carried out as described previously. ${ }^{29}$ Briefly, COCs with one or two layers expanded, one-half of the cumulus expanded, all layers expanded other than last layers of corona radiata or all layers expanded including corona radiate were classified as expanded COCs. All of the COCs other than expanded COCs such as COCs without cumulus expansion (no observable sign of cumulus expansion) were classified as non-expanded COCs. Next, the oocytes were picked up from the maturation droplet and transferred into another Petri dish containing DPBS. After denudation oocytes were fixed in acid-alcohol (acetic acid:ethanol is 1:3) for 2 days and stained with aceto-glycerol (glycerol:acetic acid:water is 1:1:3) and observed under a differential interference contrast (DIC) microscope (Olympus Inc., USA) to examine the meiotic stages of oocytes. ${ }^{30}$

\section{Ethics statement}

All the experimental procedures of this study were approved and supervised by the committee for ethical standard of research in Bangladesh agricultural university research system, Bangladesh agricultural university (Reference number: BAURES/ESRC/691/2020).

\section{Statistical analysis}

All data were subjected to one-way ANOVA and the significance of difference among means was determined by the Duncan's multiple range test (DMRT). All statistical analyses were conducted using SPSS software for windows (IBM SPSS Statistics 22). Values of $\mathrm{p}<0.05$ were considered significant.

\section{RESULTS}

\section{Effects of sucrose on vitrification of buffalo oocytes}

The number of oocytes recovered after vitrification did not differ significantly $(\mathrm{p}<0.05)$ due to different concentrations of sucrose (Table 1). A higher number of morphologically normal oocytes were found in $0.5 \mathrm{M}$ sucrose treated oocytes than in $0.25 \mathrm{M}$ and $0 \mathrm{M}$ groups. A significantly higher $(\mathrm{p}<0.05)$ number of oocytes showed cumulus expansion in $0.5 \mathrm{M}$ sucrose treated group than others (Table 1, Figure 1). The number of oocytes found in metaphase I, anaphase I and telophase I stages did not significantly $(\mathrm{p}<0.05)$ differ within the treatment groups (Table 1). The number of degenerated oocytes also did not differ significantly $(\mathrm{p}<0.05)$ among the groups. However, none of those oocytes developed to metaphase II stage irrespective of sucrose levels in the vitrification medium (Table 1, Figure 1).

\section{Effects of glycerol on vitrification of buffalo oocytes}

Table 2 showed that number of oocytes recovered after vitrification and these numbers did not differ significantly $(\mathrm{p}<0.05)$ among the treatment groups of glycerol. After vitrification, oocytes showed various abnormal morphological changes including shrinkage of oocyte cytoplasm and nucleus, abnormal shape of oocytes, too dark or clear cytoplasm and dissociation of cumulus cells. However, the number of morphologically normal oocytes was significantly $(\mathrm{p}<0.05)$ higher in $5 \mathrm{M}$ glycerol level and $10 \mathrm{M}$ than in the control $(0 \mathrm{M})$ group. The percentage of oocytes showing cumulus expansion was higher in $5 \mathrm{M}$ glycerol and $10 \mathrm{M}$ than the control groups. In addition, a proportion of oocytes treated with $5 \mathrm{M}$ glycerol reached to the MII stage (Figure 2). Oocytes from control group showed significantly $(\mathrm{p}<0.05)$ higher percentage at the MI stage than $5 \mathrm{M}$ and $10 \mathrm{M}$ glycerol. However, proportions of oocytes in anaphase I and telophase I did not vary among the treatment groups. Proportions of degenerated oocytes also did not differ among groups.

Table 1: Morphological status and in vitro maturation of buffalo oocytes vitrified with sucrose.

\begin{tabular}{|c|c|c|c|c|c|c|c|c|}
\hline \multirow{2}{*}{$\begin{array}{l}\text { Concentrations } \\
\text { of sucrose } \\
\text { (M) }\end{array}$} & \multirow{2}{*}{$\begin{array}{l}\text { Total } \\
\text { number of } \\
\text { oocytes } \\
\text { examined }\end{array}$} & \multirow{2}{*}{$\begin{array}{l}\text { Number }(\%) \\
\text { of oocytes } \\
\text { recovered } \\
\text { after } \\
\text { vitrification }\end{array}$} & \multirow{2}{*}{$\begin{array}{l}\text { Number }(\%) \text { of } \\
\text { morphologicall } \\
\text { y normal } \\
\text { oocytes }\end{array}$} & \multirow{2}{*}{$\begin{array}{l}\text { Number } \\
(\%) \text { oocytes } \\
\text { with } \\
\text { cumulus } \\
\text { expansion }\end{array}$} & \multicolumn{4}{|c|}{$\begin{array}{l}\text { Number }(\%) \text { of oocytes at different } \\
\text { stages of meiotic division }\end{array}$} \\
\hline & & & & & MI & $\mathbf{A I}$ & TI & DE \\
\hline $\mathbf{0}$ & 20 & $17(85)$ & $12(60)^{b}$ & $9(52)^{\mathrm{c}}$ & $4(45)$ & $2(22)$ & $2(22)$ & $1(11)$ \\
\hline 0.25 & 20 & $18(90)$ & $15(75)^{\mathrm{a}}$ & $15(83)^{b}$ & $6(40)$ & $4(27)$ & $3(20)$ & $2(13)$ \\
\hline 0.5 & 20 & $18(90)$ & $16(80)^{\mathrm{a}}$ & $18(100)^{\mathrm{a}}$ & $7(39)$ & $5(27)$ & $4(22)$ & $2(11)$ \\
\hline
\end{tabular}

${ }^{a-c}$ Values with different superscripts in the same column differed $(\mathrm{p}<0.05)$; the meiotic stages of oocytes in this experiment were classified as $\mathrm{MI}=$ metaphase $\mathrm{I}$; $\mathrm{AI}=$ Anaphase $\mathrm{I}$; $\mathrm{TI}=$ Telophase $\mathrm{I}$; DE=Degenerate. 


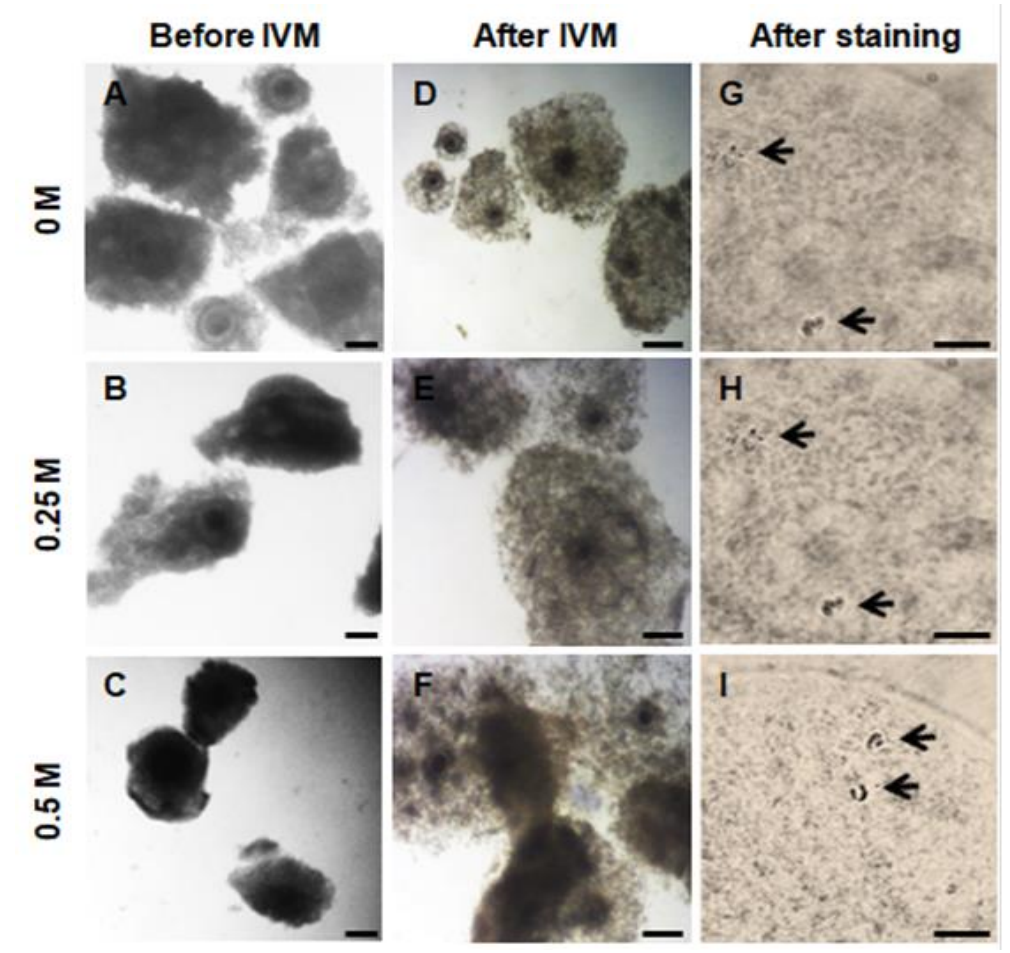

Figure 1: Typical morphologies of COCs vitrified with sucrose; COCs vitrified with $0,0.25$ and $0.5 \mathrm{M}$ of sucrose are shown in A, B and C, respectively; similarly the cumulus cell expansion of these COCs after IVM are shown in $\mathrm{D}, \mathrm{E}$ and $\mathrm{F}$, respectively; the assessment of meiotic progression of oocyte vitrified with $0,0.25$ and $0.5 \mathrm{M}$ of sucrose are shown in G, H and I, respectively; scale bars represents $100 \mu \mathrm{m}$ (in A, B and C), $200 \mu \mathrm{m}$ (in D, E and F) and 10 $\mu \mathrm{m}$ (in $\mathrm{G}, \mathrm{H}$ and $\mathrm{I})$, respectively.

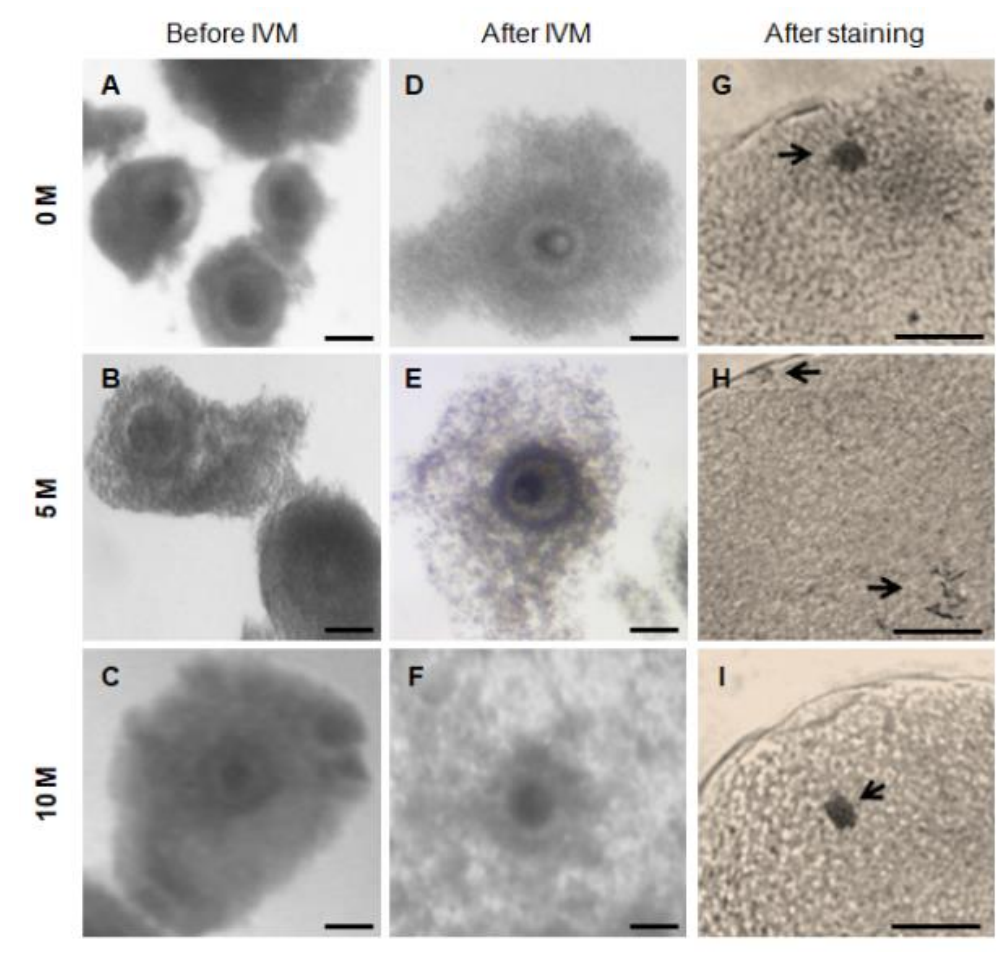

Figure 2: Typical morphologies of COCs vitrified with $0.5 \mathrm{M}$ sucrose and glycerol; COCs recovered after vitrification with 0,5 and $10 \mathrm{M}$ of glycerol are shown in A, B and C, respectively; similarly the cumulus cell expansions of these COCs after IVM are shown in D, E and F, respectively; the assessments of meiotic progression of oocyte vitrified with 0,5 and $10 \mathrm{M}$ of glycerol are shown in G, H and I, respectively; scale bars represents 100 $\mu \mathrm{m}$ (in left and middle panel) and $20 \mu \mathrm{m}$ (in right panel), respectively. 
Table 2. Morphological status and in vitro maturation of buffalo oocytes vitrified with glycerol.

\begin{tabular}{|c|c|c|c|c|c|c|c|c|c|}
\hline \multirow{2}{*}{$\begin{array}{l}\text { Concentratio } \\
\text { ns of glycerol } \\
\text { (M) }\end{array}$} & \multirow{2}{*}{$\begin{array}{l}\text { Total } \\
\text { number } \\
\text { of oocytes } \\
\text { examined }\end{array}$} & \multirow{2}{*}{$\begin{array}{l}\text { Number }(\%) \text { of } \\
\text { oocytes } \\
\text { recovered after } \\
\text { vitrification }\end{array}$} & \multirow{2}{*}{$\begin{array}{l}\text { Number }(\%) \text { of } \\
\text { morphologically } \\
\text { normal oocytes }\end{array}$} & \multirow{2}{*}{$\begin{array}{l}\text { Number }(\%) \\
\text { oocytes with } \\
\text { cumulus } \\
\text { expansion }\end{array}$} & \multicolumn{5}{|c|}{$\begin{array}{l}\text { Number (\%) of oocytes at different } \\
\text { stages of meiotic division }\end{array}$} \\
\hline & & & & & MI & AI & $\mathbf{T I}$ & MII & DE \\
\hline $\mathbf{0}$ & 16 & $15(93)$ & $12(75)^{b}$ & $8(56)^{b}$ & $3(43)^{\mathrm{a}}$ & $2(25)$ & $2(25)$ & 0 & $1(7)$ \\
\hline 5 & 20 & $20(100)$ & $17(87)^{\mathrm{a}}$ & $17(87)^{\mathrm{a}}$ & $4(25)^{\mathrm{b}}$ & $4(25)$ & $4(25)$ & $3(18)$ & $2(12)$ \\
\hline 10 & 16 & $16(100)$ & $14(87)^{\mathrm{a}}$ & $14(87)^{\mathrm{a}}$ & $4(28)^{b}$ & $4(28)$ & $4(28)$ & 0 & $2(16)$ \\
\hline
\end{tabular}

\section{DISCUSSION}

Permeating and non-permeating cryoprotectants are used to prevent intracellular ice formation during vitrification. Permeating cryoprotectants penetrate the cell membrane and prevent ice crystallization. They form hydrogen bonds with intracellular water molecules and decrease the freezing temperature. PG, EG, glycerol and DMSO are permeating cryoprotectants. On the other hand, nonpermeating cryoprotectants dehydrate the intracellular water. They are used together with permeating cryoprotectants to increase the concentration of the permeating cryoprotectants inside the cell and prevent icecrystal formation. Sucrose, galactose, trehalose and macromolecules are used as non-permeating cryoprotectants. Glycerol is the first effective cryoprotectant in the history of cryobiology. ${ }^{31}$ In the present study, vitrification in sucrose-free medium, containing EG and DMSO caused degeneration of fully grown buffalo oocytes and dissociation of their surrounding cumulus cells. Oocytes treated with sucrose were protected from cryo-damage and showed normal morphology, especially in terms of the integrity of the oocytes and cumulus cells after vitrification. Sucrose protects the oocytes in porcine primordial follicles from cryo-damage caused by vitrification. ${ }^{27}$ Oocytes treated with sucrose $(0.25 \mathrm{M}$ and $0.5 \mathrm{M}$ ) resumed meiosis but did not mature to the MII stage. However, when glycerol was added in sucrose supplemented media, a proportion of the vitrified oocytes developed to the MII stage. Similar results were obtained by Yamada et al who investigated the effects of warming procedure on in vitro matured buffalo oocytes vitrified by cryotop. ${ }^{32}$ Survival and cleavage rates as well as efficiency of vitrification were significantly higher in oocytes treated with higher concentration of glycerol. Wani et al vitrified buffalo oocytes with mini-straw and reported that immature buffalo oocytes vitrified with DMSO, EG, $\mathrm{PROH}$ and glycerol together with $0.5 \mathrm{M}$ sucrose matured in vitro and developed to the blastocyst stage. ${ }^{7}$

In the present study, EG and glycerol in combination supported maximum protection of buffalo oocytes from cryo-injury and as glycerol is less permeable, it protects cytoplasmic membrane from cryo-injury. EG protects the intracellular structures of oocytes as it is more permeable. ${ }^{33}$ Thus, ultimately, the oocytes maintain their potential for further development, meiotic maturation. The proportions of oocytes matured after vitrifcation in glycerol-containing media were comparable to the results obtained by Hammam et al. ${ }^{34}$ The rate of maturation of vitrified oocytes was lower than the fresh control oocytes where the vitrification and warming process changed the physicochemical characteristics of intracellular lipids and such changes caused the oocyte incapable of meiotic progression. ${ }^{35}$ Moreover, it has been reported that glycerol causes an osmotic change to the cytoplasm because of its low membrane permeability. This leads to a decrease in survival rate of oocytes due to osmotic stress produced by the cryoprotectants as a result of low permeability of glycerol and more water penetration to the oocytes than the glycerol. ${ }^{36}$ It has been reported that cryoprotectants have a toxic effect on mammalian oocytes. ${ }^{37}$

In the present study, vitrification and warming were carried out with the help of cryotop. This may be the reason for the higher recovery and survival rate of oocytes in this study compared to the results of Hammam et al. ${ }^{38}$ The cryotop method is the most effective way of cryopreservation of human embryos and has been employed in approximately 230 IVF hospitals in 8 countries during the early of $2000 \mathrm{~s} .{ }^{39}$ In-straw vitrification of oocytes causes a delay in heat loss which results an intracellular recrystallization during the warming process. ${ }^{40}$ An alternate cryo-device is required to support the cooling and warming rates during vitrification and warming. ${ }^{41}$ Cryotops and open-pull straw (OPS) improved the cooling rate by reducing the surface to volume ratio and exposing vitrification drop directly into $\mathrm{LN}_{2}{ }^{22,42}$

Vitrification of buffalo oocytes with sucrose and glycerol increased the percentages of oocytes with cumulus expansion. Oocytes directly affect mouse granulosa cell function in culture condition. ${ }^{43,44}$ Removal of oocytes using micromanipulation from oocyte-cumulus cell complexes prevents FSH-induced mucification and expansion of cumulus cells. Mouse oocytes secrete a factor named cumulus expansion-enabling factor. Now, the predicted cumulus expansion-enabling factor has been identified as growth differentiation factor-9 (GDF9) in mice and it has been reported that mouse oocytes regulate energy production by granulosa cells through oocytederived bone morphogenetic protein-15 (BMP15). ${ }^{45}$ In the present study, it is thought that the sucrose and glycerol protect cumulus-oocyte complexes from cryo-injury, which in turn promotes the secretion of oocyte-derived GDF9 and BMP15 and expansion of cumulus cells in the experimental conditions. 


\section{CONCLUSION}

In conclusion, sucrose was useful in protecting buffalo oocytes from cryo-injury, however, it was unable to support the development of oocytes after vitrification and warming. On the other hand, glycerol maintained the developmental ability of buffalo oocytes. However, the mechanism that regulates the in vitro maturation of glycerol treated buffalo oocytes was not understood clearly. Moreover, in the present study, buffalo oocytes were vitrified with a combination of sucrose $(0.5 \mathrm{M})$ and glycerol $(5 \mathrm{M})$ in order to maintain its developmental competence. Further studies are required to determine the appropriate combination of the two cryo-protectant substances since the concentration of sucrose used with the varying amount of glycerol in this study was constant.

Funding: The World Academy of Science (TWAS) and Ministry of Science and Technology, Government of the People's Republic of Bangladesh and University Grants Commission of Bangladesh

Conflict of interest: None declared

Ethical approval: The study was approved by the Institutional Ethics Committee

\section{ACKNOWLEDGEMENTS}

We are thankful to Dr. Steve Clark, Senior Research Scientist, Agriculture Research \& Development, Australia, for his critical suggestions for improvement of this manuscript.

\section{REFERENCES}

1. Warriach DM, Mcgill RD, Bush WPC, Chohan KR. A review of recent developments in buffalo reproduction. Asian-Australas $\mathbf{J}$ Anim Sci. 2015;28(3):451-5.

2. Gasparrini B. In vitro embryo production in buffalo species: state of the art. Theriogenology. 2002;57(1):237-56.

3. Kumar A, Solanki VS, Jindal SK, Tripathi VN, Jain GC. Oocyte retrieval and histological studies of follicular population in buffalo ovaries. Anim Reprod Sci. 1997;47(3):189-95.

4. Fahy GM, MacFarlane DR, Angell CA, Meryman HT. Vitrification as an approach to cryopreservation. Cryobiology. 1984;21(4):407-26.

5. Parnpai R, Liang Y, Ketudat-Cairns M, Somfai T, Nagai T. Vitrification of buffalo oocytes and embryos. Theriogenology. 2016;86(1):214-20.

6. Shaw JM, Kuleshova LL, MacFarlane DR, Trounson AO. Vitrification properties of solutions of ethylene glycol in saline containing PVP, Ficoll, or dextran. Cryobiology. 1997;35(3):219-29.

7. Wani NA, Maurya SN, Misra AK, Saxena VB, Lakhchaura BD. Effect of cryoprotectants and their concentration on in vitro development of vitrifiedwarmed immature oocytes in buffalo (Bubalus bulalis). Theriogenology. 2004;61(5):831-42.
8. Vieira AD, Mezzalira A, Barbieri DP, Lehmkuhl RC, Rubin MI, Vajta G. Calves born after open pulled straw vitrification of immature bovine oocytes. Cryobiology. 2002;45(1):91-4.

9. Kuleshova LL, MacFarlane DR, Trounson AO, Shaw JM. Sugars exert a major influence on the vitrification properties of ethylene glycol-based solutions and have low toxicity to embryos and oocytes. Cryobiology. 1999;38(2):119-30.

10. Leibo SP. Water permeability and its activation energy of fertilized and unfertilized mouse ova. J Membr Biol. 1980;53:179-88.

11. Mazur P. Equilibrium, quasi-equilibrium, and nonequilibrium freezing of mammalian embryos. Cell Biophys. 1990;17:53-92.

12. Kasai M, Komi JH, Takakamo A, Tsudera H, Sakurai T, Machida T. A simple method for mouse embryo cryopreservation in a low toxicity vitrification solution, without appreciable loss of viability. J Reprod Fertil. 1990;89(1):91-7.

13. Hochi S, Terao T, Kamei M, Kato M, Hirabayashi M, Hirao M. Successful vitrification of pronuclear-stage rabbit zygotes by minimum volume cooling procedure. Theriogenology. 2004;61(2-3):267-75.

14. Schiewe MC, Rall WF, Stuart LD, Wildt DE. Analysis of cryoprotectant, cooling rate and in situ dilution using conventional freezing or vitrification for cryopreserving sheep embryos. Theriogenology. 1991;36(2):279-93.

15. Oberstein N, O'Donovan MK, Bruemmer JE, Seidel GE, Carnevale EM, Squire EL. Cryopreservation of equine embryos by open pulled straw, cryoloop, or conventional slow cooling methods. Theriogenology. 2001;55(2):607-13.

16. Delval A, Ectors FJ, Touati K, Beckers JF, Ectors F. Vitrification of bovine embryos produced in vitro: survival, hatching and pregnancy rates. Theriogenology. 1996;45(1):178.

17. Hufana-Duran D, Pedro PB, Venturina HV, Hufana RD, Salazar AL, Duran PG, et al. Post-warming hatching and birth of live calves following transfer of in vitro-derived vitrified water buffalo (Bubalus bubalis) embryos. Theriogenology. 2004;61(78):1429-39.

18. Mukaida T, Nakamura S, Tomiyama T, Wada S, Kasai M, Takahashi K. Successful birth after transfer of vitrified human blastocysts with use of a cryoloop container less technique. Fertil Steril. 2001;76(3):61820.

19. Nakagata N. High survival rate of unfertilized mouse oocytes after vitrification. J Reprod Fertil. 1989;87(2):479-83.

20. Hamano S, Koikeda A, Kuwayama M, Nagai T. Fullterm development of in vitro matured, vitrified and fertilized bovine oocytes. Theriogenology. 1992;38(6):1085-90.

21. Dhali A, Manik RS, Das SK, Singla SK, Palta P. Vitrification of buffalo (Bubalus bubalis) oocytes. Theriogenology. 2000;53(6):1295-303. 
22. Kuwayama M. Highly efficient vitrification for cryopreservation of human oocytes and embryos: the cryotop method. Theriogenology. 2007;67(1):73-80.

23. Wright DL, Eroglu A, Toner M, Toth TL. Use of sugars in cryopreserving human oocytes. Reprod Biomed Online. 2004;9(2):179-86.

24. Huang J, Li Q, Zhao R, Li W, Han Z, Chen X, et al. Effect of sugars on maturation rate of vitrified-thawed immature porcine oocytes. Anim Reprod Sci. 2008;106(1-2):25-35.

25. El-Shalofy AS, Moawad AR, Darwish GM, Ismail ST, Badawy ABA, Badr MR. Effect of different vitrification solutions and cryodevices on viability and subsequent development of buffalo oocytes vitrified at the germinal vesicle $(\mathrm{GV})$ stage. Cryobiology. 2017;74:86-92.

26. Gupta MK, Uhm SJ, Lee HT. Cryopreservation of immature and in vitro matured porcine oocytes by solid surface vitrification. Theriogenology. 2007;67(2):238-48.

27. Moniruzzaman M, Bao RM, Taketsuru H, Miyano T. Development of vitrified porcine primordial follicles in xenografts. Theriogenology. 2009;72(2):280-8.

28. Bao RM, Yamasaka E, Moniruzzaman M, Hamawaki A, Yoshikawa M, Miyano T. Development of vitrified bovine secondary and primordial follicles in xenografts. Theriogenology. 2010;74(5):817-27.

29. Maruska DV, Leibfried ML, First NL. Role of calcium and the calcium-calmodulin complex in resumption of meiosis, cumulus expansion, viability and hyaluronidase sensitivity of bovine cumulusoocyte complexes. Biol Reprod. 1984;31(1):1-6.

30. Islam MN, Alam MH, Khatun A, Akter I, Modak AK, Hashem MA, et al. Effects of stem cell factor on in vitro growth of buffalo oocytes. Theriogenology. 2020;142:114-9.

31. Rajan R, Matsumura K. Development and application of cryoprotectants. Adv Exp Med Biol. 2018;1081:339-54.

32. Yamada C, Caetano HV, Simões R, Nicacio AC, Feitosa WB, Assumpção ME, et al. Immature bovine oocyte cryopreservation: comparison of different associations with ethylene glycol, glycerol and dimethylsulfoxide. Anim Reprod Sci. 2007;99(34):384-8.

33. Hurtt AE, Landim-Alvarenga F, Seidel GE, Squires EL. Vitrification of immature and mature equine and bovine oocytes in an ethylene glycol, ficoll and sucrose solution using open-pulled straws. Theriogenology. 2000;54(1):119-28.

34. El-Shahat KH, Hammam AH. Effect of different types of cryoprotectants on developmental capacity of vitrified-thawed immature buffalo oocytes. Anim Reprod. 2014;11(4):543-8.
35. Kim JY, Kinoshita M, Ohnishi M, Fukui Y. Lipid and fatty acid analysis of fresh and frozen-thawed immature and in vitro matured bovine oocytes. Reproduction. 2001;122(1):131-8.

36. Martino A, Songsasen N, Leibo SP. Development into blastocysts of bovine oocytes cryopreserved by ultrarapid cooling. Biol Reprod. 1996;54(5):1059-69.

37. Purohit GN, Meena H, Solanki K. Effects of vitrification on immature and in vitro matured, denuded and cumulus compact goat oocytes and their subsequent fertilization. J Reprod Infertil. 2012;13(1):53-9.

38. Hammam M, El-Shahat H. Vitrification of immature and mature buffalo oocytes in glycerol solution by a simple method. Proceedings of the XII ISAH Congress on Animal Hygiene. Poland: Warsaw Agricultural University; 2005: 252-5.

39. Kuwayama M. Evidence-based embryo cryopreservation. J Mam Ova Res. 2005;22:193-7.

40. Morató R, Izquierdo D, Paramio MT, Mogas T. Cryotops versus open-pulled straws (OPS) as carriers for the cryopreservation of bovine oocytes: effects on spindle and chromosome configuration and embryo development. Cryobiology. 2008;57(2):137-41.

41. Succu S, Leoni GG, Bebbere D, Berlinguer F, Mossa F, Bogliolo L, et al. Vitrification devices affect structural and molecular status of in vitro matured ovine oocytes. Mol Reprod Dev. 2007;74(10):133744.

42. Liebermann J, Tucker MJ, Graham JR, Han T, Davis A, Levy MJ. Blastocyst development after vitrification of multipronuclear zygotes using the Flexipet denuding pipette. Reprod Biomed Online. 2002;4(2):146-50.

43. Vanderhyden BC, Caron PJ, Buccione R, Eppig JJ. Developmental pattern of the secretion of cumulus expansion-enabling factor by mouse oocytes and the role of oocytes in promoting granulosa cell differentiation. Dev Biol. 1990;140(2):307-17.

44. Buccione R, Vanderhyden BC, Caron PJ, Eppig JJ. FSH-induced expansion of the mouse cumulus oophorus in vitro is dependent upon a specific factor (s) secreted by the oocyte. Dev Biol. 1990;138(1):1625.

45. Elvin JA, Clark AT, Wang P, Wolfman NM, Matzuk MM. Paracrine actions of growth differentiation factor-9 in the mammalian ovary. Mol Endocrinol. 1999;13(6):1035-48.

Cite this article as: Hossain MA, Akter S, Miraz MFH, Islam MN, Bari J, Alam MH, et al. Effects of sucrose and glycerol on vitrification of buffalo oocytes. Int J Reprod Contracept Obstet Gynecol 2021;10:2558-64. 